\title{
The Role of Leadership in Engaging Parents in United Arab Emirate Schools
}

\author{
Shaikah Al-Taneiji ${ }^{1}$ \\ ${ }^{1}$ Foundations of Education, College of Education, United Arab Emirates University, Al-Ain, UAE \\ Correspondence: Shaikah Al-Taneiji, Foundations of Education, College of Education, United Arab Emirates \\ University, Al-Ain, UAE. E-mail: shaikaha@uaeu.ac.ae
}

Received: November 13, 2012 Accepted: November 26, 2012 Online Published: December 10, 2012

http://dx.doi.org/10.5539/ies.v6n1p153 URL: http://dx.doi.org/10.5539/ies.v6n1p153

\begin{abstract}
The aim of this study is to explore the practices used by school leaders (principals, vice principals and social workers) to encourage parental involvement in UAE schools, and the differences in these practices based on their gender, school level and job position. A questionnaire was distributed to teachers in schools in Dubai, Sharjah, Fujairah and Al-Ain, and 377 responses were collected. The study revealed that school leaders in UAE schools often communicate with parents. Further, they frequently engage parents in school decisions related to students' activities and behavior. The results also show that school leaders involve parents in their children's education in different ways, and that these differences are linked to the gender, school level and job position of those leaders.
\end{abstract}

Keywords: school leaders, parental involvement, United Arab Emirates schools

\section{Introducation}

Parental involvement in United Arab Emirates (UAE) schools depends on the school's own effort and the principal's network. Aside from a requirement by the Ministry of Education that every school has a Parents' Association, a school principal has no legal obligation to involve parents in their child's school. Most of the work done by a Parents' Association is advisory, and focuses on organizing school activities (Al-Taneiji, 2001; Al Sumaiti, 2012). "Many schools fail to engage Emirati parents appropriately and use communication channels that do not take cultural considerations into account, such as when a phone call is more appropriate than written communication" (Al Sumaiti, 2012, p.1).

Since leadership is the cornerstone in building a culture that supports the involvement of parents in their children's education (Mapp, 2003), school practices to involve parents is crucial. School leaders may agree that parental involvement in schools is crucial; however, their practices in reality could conflict with their beliefs (Lloyd-Smith \&Baron, 2010). Barnyak and McNelly (2009) examined the practices and beliefs of administrators and teachers on parental involvement in an urban school district in the United States, and found evidence that, while teachers and administrators believed in the importance of parental involvement, their practices in their schools and classrooms remained inconsistent with their beliefs.

The aim of this study is to explore the practices undertaken by school leaders (principals, vice principals and social workers) to encourage parental involvement in UAE schools. The following questions guided the study:

RQ1: What types of activities do school principals, vice principals and social workers practise in order to encourage active parental involvement in UAE schools?

RQ2: Is there a statistically significant difference in the way these practices of parental involvement by school leaders are carried out, based on gender, school level and job position?

For the purpose of this study, school leadership is not limited to the school principal, because leadership is defined as "a process of influence based on clear values and beliefs and leading to a "vision' for the school" (Bush \& Glover 2002. p. 31). Therefore, this study also includes vice principals and social workers as school leaders, as they contribute to school effectiveness by dealing with students' disruptive behavior and their work involves interacting with parents (Badri, 1998). The social worker has all the pertinent academic, psychological, social and economic information on the students. The social worker plans and organizes student activities, such as open days and sports days. Further, social workers contact parents directly and gather information on the students and their home environment (Sills-Briegel, Bryant, \& Al Hashimi, 2009). 
Establishing successful parental involvement in UAE schools brings new challenges for school leaders, who must determine how to generate meaningful parental involvement that benefits students, schools and parents alike. Few studies have explored this area of study in the UAE. This study is expected to add to the general body of literature on parental involvement in schools, specifically in the UAE.

\section{Limitations}

One of limitations of this study is that the data collection was obtained from school leaders, not from parents. This occurred because many of the parents had a poorly developed understanding of the role of a school leader. A further limitation of the study is that the results of the study are based on self-reported data that was obtained by a survey instrument that did not preclude biased responses.

\section{Literature Review}

Numerous studies have reported that parental involvement in children's education is essential for student achievement (Barton \& Coley, 2007; Dixon, 2008; Gordon \& Louis 2009; Hill \& Tyson, 2009; Henderson \& Mapp, 2002; Lunenburg and Irby, 2002; Simon, 2001; Van Voorhis, 2001). Parental involvement may be defined as "parents' involvement in children's education to promote their academic and social success" (Fishel \& Ramirez, 2005). Epstein (1995) described parental involvement in children's education through six types of activities: parenting, communicating, learning at home, volunteering, decision-making and community connections. These six types of activities will be examined in greater depth in this study.

Involving parents effectively in schools is challenging. According to Mitchell (2008), some of the challenges arise because most school administrators and teachers do not work with parents as equal partners in decision-making, largely because of their negative attitude to parents. Some schools see involving parents as a waste of time or an extra burden. Bæck (2010a) examined teachers' attitudes and experiences and found that most teachers value the interaction with parents and consider them to be supporters. On the other hand, teachers also stress their own professionalism and deliberately try to keep a distance between themselves and the parents. Jacobs (2008) carried out interviews with 21 grade 1-4 teachers and found that teachers value and use communication to meet their students' curriculum needs. Further, she reported that the views of teachers on parental involvement were based on models exhibited by their mentor teachers, their colleagues, the school administration and their own parents.

This literature review seeks to point out that parental involvement in schools declines as students move to higher grades (Spera, 2005). Parents face difficulties in becoming involved at the secondary school level; these difficulties include not knowing what is required of them, the fact that the workload at this level requires more effort from them, and their own negative school experiences (Dixon, 2008). The education level of the parents could also impact on their involvement. Parents with a low level of education find it particularly difficult to collaborate with schools, due to feelings of inadequacy about their own level of academic knowledge (Bæck, 2010b).

Usually, in secondary schools, parental expectations, academic socialization and guidance have more influence on students' learning, than the visibility of parents at school events or working on homework (Fan and Chen, 2001; Chen \& Gregory, 2010; Sanders and Epstein, 2000; Hill and Tyson, 2009). Hill and Tyson (2009) state that academic socialization, expectations for achievement, valuing education, and discussions about future plans and goals are effective for students in middle and secondary school. This suggests that parental involvement in secondary schools should be structured differently from parental involvement in elementary schools (Chen and Gregory, 2010). Simon (2004) found that parents are more likely to be involved in their children's education in high school, if schools conduct activities that encourage them to be involved. This finding was based on the results of a survey of 11,000 parents of the high school seniors who participated in the National Educational Longitudinal Study of 1988.

Many models in western literature describe the role of parents in their children's education. Berger's model (1991) describes how parents should be involved in schools. The roles included in this model are: parents as teachers of their own children, parents as employees of a school, parents as volunteers, parents as resources, and parents as policy-makers. Chavkin and Williams (1993) later revised and emphasized some of these roles and added others. These roles consisted of parents as audience, parents as tutors, parents as program supporters, parents as policy-makers, parents as advocates, and parents as co-learners. Many empirical studies have examined the different types of parental involvement and their impact on student achievement. Harris and Goodall (2008), for instance, conducted a qualitative study, using the case-study method, on 20 schools in England, using documentation and performance analysis from each. Their results showed that parental 
involvement in children's learning in the home has more effect on students' achievement than parental involvement in school activities.

In the United States, Epstein (2008) described six types of parental involvement, detailing how schools should engage parents. They are:

- Parenting: Helping parents with parenting and child-rearing skills, understanding child development and supporting home conditions that encourage child achievement;

- Communicating with parents regarding school programs and student progress through effective two-way communication;

- Volunteering: Involving parents as volunteers in the school or outside school, to support school programs and activities;

- Learning at home: Involving parents in learning activities with their children at home, such as reading with their children or showing an interest in their homework;

- Decision-making: Involving parents in schools as decision-makers in school governance through Parent-Teacher Associations (PTAs), school councils and committees;

- And collaborating with the community where parents work with different organizations and groups to support school activities and programs.

The literature confirms that the way in which schools involve parents correlates to the level of their involvement, and is crucial if increased involvement is sought. For example, Bailey, Silvern, Brabham and Ross (2004) found that interactive reading homework designed by schools could increase parental involvement in reading homework, and, as a result, student achievement. Feuerstein (2000) found that teacher communication with parents, parent volunteerism, and involvement in parent-teacher organizations, can all be increased when teachers contact parents. Haastrup and Arogundade (2009) investigated the relationship between parents' involvement in school administration and the effectiveness of secondary schools in Nigeria, by surveying 1200 teachers, 300 parents and 60 principals from 60 secondary schools in that country. The researchers found that while parents were heavily involved in the school administration, there was no relationship between parental involvement in school administration and the effectiveness of schools. They suggested that, if they wish to improve the effectiveness of schools, decision-makers should focus on how students learn. A supportive study was also conducted by Boaduo, Milondzo and Adjei (2009) in South Africa. This study reported that parental involvement in school governance contributed to the effectiveness of teachers in improving student learning and performance.

Parental involvement in children's education can differ according to culture and ethnicity. Huntsinger and Jose (2008) investigated the types of parental involvement in two cultures within the United States. They found that, due to cultural traditions, Chinese-American parents and European American parents differed in the way they were involved in their children's education. European-American parents like to volunteer in schools, but Chinese-American parents like to focus more on teaching their children at home.

In short, parents have a crucial role in their children's education. Therefore, schools should recognize different types of parental involvement in order to engage parents in their children's education at different school levels. They also need to deal with any obstacles that could prevent parents from being involved.

\section{The Context of the Study}

As this study was conducted in the UAE, it is useful to understand the UAE education system of education a little more. In the UAE, the Ministry of Education is charged with providing educational services to five emirates: Sharjah, Ajman, Ras al-Khaimah, Fujairah and Umm al-Quwain. The Abu Dhabi Education Council, established in 2005, oversees educational services in the emirate of Abu Dhabi. In 2006, the Knowledge and Human Development Authority (KHDA), was established to provide and supervise educational services in Dubai (International Bureau of Education, 2011).

The school structure includes three basic education segments. The first covers grades 1-5, while the second covers grades 6-9. The students then move to the third segment, which is the secondary education segment, which lasts for three years and covers grades 10-12. The UAE, which is undergoing curriculum major reform, has 721 government schools. Therefore, many programs and initiatives have been set in motion to improve the quality of school education. These involve an increased emphasis on the use of technology in teaching and learning, English language learning, and consideration of where the students should be focused (International Bureau of Education, 2011). School administrators, teachers and staff are now appointed centrally. Schools are 
segregated by gender. UAE schools generally have one or two vice-principals, depending on the number of students. This study will be placed in the above context, tying in aspects of the local culture that influence the ways in which school leader involve parents in school activities and student education.

\section{Methodology}

A quantitative survey was distributed to principals, vice principals and social workers from four educational districts in UAE. The questionnaire was distributed and collected by a research office from each educational zone and then sent to the researcher.

\subsection{Participants}

The four educational zones were selected at random, and included Dubai, Sharjah, Fujairah, and Al-Ain, out of the 10 UAE education zones. Of the total of 600 questionnaires that were sent out, 377 were received back, giving a response rate of $62.8 \%$. The profile of the participants was as follows: $110(29.2 \%)$ principals, 117 $(31.0 \%)$ vice principals, and $150(39.8 \%)$ social workers. There were also $136(36.1 \%)$ males and $241(63.9 \%)$ females in the sample. All the participants were teaching in the three basic educational levels: the first segment-116 (30.8\%), the second segment-153 (40.6\%), and secondary-107 (28.4\%).

\subsection{Instrument}

The survey instrument was a questionnaire, originally designed by Salinas, Epstein and Sanders (1999). This was adapted for the purpose of this study, after obtaining permission from the authors. The instrument was modified by the researcher with the aim of measuring school, family and community partnerships. The questionnaire consisted of two sections. In section A, respondents were asked to respond to demographic questions regarding their years of experience, level of education, gender and school type. In section B, respondents were asked to rate their practices to encourage parents to be engaged in school activities, based on a five-point Likert scale: 'never' $(=1)$; rarely $(=2)$; sometimes $(=3)$; often $(=4)$, and always $(=5)$. This section contained a list of practices used by educators, based on the six types of involvement listed in Epstein's model. The section consisted of 49 items classified under six areas of involvement that schools practice to engage parents: Parenting, Communicating, Learning at Home, Volunteering, Involving in Making Decisions, and Communicating with Community.

The validity of the questionnaire was established through an evaluation of the initial draft of the questionnaire by a group of university professors from the Faculty of Education, UAE University. Modifications based on their suggestions were made. Accordingly, some questions were shortened and others were eliminated or modified. The internal reliability of the entire questionnaire and its separate components was established using Cronbach's Alpha. The result of this analysis indicated that the internal reliability of the questionnaire was high (.96). In addition, the internal reliability of each of the six components of the questionnaire was estimated, and the results were summarized in Table 1. These values indicated that all components have acceptable internal reliability.

Table 1. Number of Items and Internal Reliability of Each of the Six Components

\begin{tabular}{lll}
\hline Component & Number of Items & $\begin{array}{l}\text { Cronbach's } \\
\text { Alpha }\end{array}$ \\
\hline Parenting & 6 & .83 \\
Communicating & 20 & .90 \\
Learning at home & 3 & .80 \\
Volunteering & 11 & .92 \\
Involving in Making Decisions & 5 & .79 \\
Communicating with Community & 4 & .77 \\
\hline
\end{tabular}

\section{Data Analysis}

To answer RQ1 (What types of activities do school principals, vice principals and social workers carry out in order to encourage active parental involvement in UAE schools?), descriptive tests were first conducted to calculate means. To answer the second question (Is there a statistically significant difference due to gender, school level, and job position?), an ANOVA was carried out to find out the difference among school levels and job position (principal, vice principal and social worker), and a t test was used to establish the gender difference. 


\section{Results}

To answer RQ1: "What types of activities do school principals, vice principals and social workers carry out in order to encourage active parental involvement in UAE schools?", the responses of participants were analyzed through an examination of the results of the descriptive statistical tests, and the results were summarized according to the six components of parental involvement types (see table 2). The results indicate that Communication activities $(\mathrm{M}=4.15)$, and involving parents in making decisions for schools $(\mathrm{M}=4.06)$, are activities that school leaders are practicing most to involve parents in their children's education, while encouraging parents in parenting $(\mathrm{M}=3.59)$, learning at home $(\mathrm{M}=3.59)$, volunteering $(\mathrm{M}=3.86)$ and communicating with Community $(\mathrm{M}=3.84)$ were less practiced.

Table 2. Descriptive Analysis for Parental Involvement Types Activities of School leaders

\begin{tabular}{llllll}
\hline Parental Involvement Types & $\mathrm{N}$ & Minimum & Maximum & Mean & $\begin{array}{l}\text { Std. } \\
\text { Deviation }\end{array}$ \\
\hline Parenting & 374 & 1.17 & 5.00 & 3.5971 & .78130 \\
Communicating & 344 & 1.60 & 5.00 & 4.1586 & .54427 \\
Learning at home & 373 & 1.00 & 5.00 & 3.5880 & .93697 \\
Volunteering & 361 & 1.00 & 5.00 & 3.8572 & .82698 \\
Involving in Making Decisions & 366 & 1.40 & 5.00 & 4.0667 & .76092 \\
Communicating with Community & 374 & 1.25 & 5.00 & 3.8389 & .81475 \\
Valid N (listwise) & 333 & & & & \\
\hline
\end{tabular}

First: Parenting, principals practice several types of activities to encourage parents of students to be engaged in schools. Providing parents with information on a good study atmosphere was the most common activity encouraged by principals $(M=4.15)$, and social workers $(M=4.37)$, and less commonly by vice principals $(3.85)$. Providing parents with books, tapes and flyers on how to raise children was also less practiced by vice principals $(\mathrm{M}=2.57)$, the principal $(\mathrm{M}=2.87)$ and the social workers $(\mathrm{M}=3.17)$. The other activities were encouraged by principals on average or a little bit above average. Similar results were observed for vice principals and social workers. Table 3 summarizes the responses of participants on the six items that make up this component.

Table 3. Responses of Principals, Vice Principals, and Social Workers on Parenting

\begin{tabular}{llll}
\hline Item & Principals & V. Principals & $\begin{array}{l}\text { Social } \\
\text { Workers }\end{array}$ \\
\hline $\begin{array}{l}\text { 1. I organize workshops to explain new information to parents on } \\
\text { how to raise their children. }\end{array}$ & & 2.69 & 3.53 \\
$\begin{array}{l}\text { 2. I ask parents to provide me with important topics to present } \\
\text { workshops about them. }\end{array}$ & 3.30 & 3.00 & 3.60 \\
$\begin{array}{l}\text { 3. I provide parents with information about their children's } \\
\text { growth in each stage. }\end{array}$ & 3.68 & 3.20 & 3.89 \\
$\begin{array}{l}\text { 4. I provide parents with books, tapes and flyers on how to raise } \\
\text { their children. }\end{array}$ & & 3.87 \\
$\begin{array}{l}\text { 5. I provide parents with information on how to provide their } \\
\text { children with good atmosphere for studying and doing } \\
\text { homework. }\end{array}$ & & 3.15 \\
$\begin{array}{l}\text { 6. I encourage parents to contact each other to exchange } \\
\text { experience on how solve their children problems. }\end{array}$ & & 4.05 \\
\hline $\mathrm{n}=333$
\end{tabular}

$\mathrm{n}=333$ 
Second: Communicating, this is the biggest factor containing 19 items. In general, it may be said that communication between school leaders and parents is well established, as most of the scores in the items in this factor were above average $(M=3)$. For principals, the most important communication with parents pertains to student achievement and attendance. Similar results were observed for social workers.

It was found that principals communicated with parents more than vice principals in most of these areas. This could be the case due to the distribution of administrative roles in schools. Asking teachers to use the school phone was the least common activity in general by vice principals $(M=2.97)$, social workers $(M=3.11$, $)$ and the principals alike $(\mathrm{M}=3.40)$. The responses of participants on each item were summarized and listed in Table 4.

Table 4. Responses of Principals, Vice Principals, and Social Workers on Communicating

\begin{tabular}{|c|c|c|c|}
\hline Item & Principals & V. Principals & $\begin{array}{l}\text { Social } \\
\text { Workers }\end{array}$ \\
\hline $\begin{array}{l}\text { 1. I provide parents with information about their children's } \\
\text { strength and weakness. }\end{array}$ & 4.55 & 4.24 & 4.73 \\
\hline 2. I ask teachers to communicate with parents. & 4.79 & 4.60 & 4.81 \\
\hline $\begin{array}{l}\text { 3. I encourage teachers to send students reports to parents that } \\
\text { show students' activities. }\end{array}$ & 4.26 & 4.24 & 4.26 \\
\hline 4. I ask teachers to use the school phone to contact parents. & 3.40 & 2.97 & 3.11 \\
\hline 5. I provide parents with teachers' phone numbers. & 4.50 & 4.47 & 4.60 \\
\hline $\begin{array}{l}\text { 6. I provide parents with information about good times to contact } \\
\text { teachers. }\end{array}$ & 4.72 & 4.29 & 4.74 \\
\hline $\begin{array}{l}\text { 7. I involve parents in the school activities that their children } \\
\text { participate in. }\end{array}$ & 4.05 & 3.91 & 3.85 \\
\hline $\begin{array}{l}\text { 8. I communicate with parents regarding students' academic } \\
\text { achievement }\end{array}$ & 4.86 & 4.39 & 4.83 \\
\hline $\begin{array}{l}\text { 9. I communicate with parents regarding regular meeting in } \\
\text { schools }\end{array}$ & 4.75 & 4.33 & 4.76 \\
\hline $\begin{array}{l}\text { 10. I communicate with parents regarding helping students in the } \\
\text { school activities. }\end{array}$ & 4.58 & 4.09 & 4.55 \\
\hline $\begin{array}{l}\text { 11. I communicate with parents regarding conducting parents' } \\
\text { council meetings. }\end{array}$ & 4.68 & 4.23 & 4.73 \\
\hline $\begin{array}{l}\text { 12. I communicate with parents regarding students' attendance } \\
\text { and absenteeism }\end{array}$ & 4.84 & 4.60 & 4.85 \\
\hline 13. I communicate with parents regarding students development & 3.87 & 3.41 & 4.03 \\
\hline 14. I communicate with parents regarding curriculum & 4.07 & 3.62 & 3.91 \\
\hline $\begin{array}{l}\text { 15. I communicate with parents regarding volunteering in school's } \\
\text { activities }\end{array}$ & 4.50 & 4.17 & 4.50 \\
\hline $\begin{array}{l}\text { 16. I communicate with parents regarding school philosophy and } \\
\text { mission. }\end{array}$ & 4.19 & 4.05 & 4.17 \\
\hline $\begin{array}{l}\text { 17. I communicate with parents regarding visiting parents in their } \\
\text { homes. }\end{array}$ & 4.35 & 3.05 & 3.32 \\
\hline $\begin{array}{l}\text { 18. I communicate with parents regarding avoiding problems that } \\
\text { could happen to students. }\end{array}$ & 3.96 & 3.89 & 4.07 \\
\hline $\begin{array}{l}\text { 19. I communicate with parents regarding distributing survey to } \\
\text { know students' weakness and strengths. }\end{array}$ & 3.56 & 3.15 & 3.56 \\
\hline
\end{tabular}

Third: Learning at home, this factor contained only three items. The results indicated that school leaders sometimes $(\mathrm{M}=3)$ encourage parents to be engaged in school issues related to students' learning at home. Social 
workers often provide parents with information that helps them to teach their children at home (M=4.05). On the other hand, borrowing educational resources from schools was the least common activity practiced by school leaders among the listed activities. The means of participants' responses on each of the items are summarized in Table 5.

Table 5. Responses of Principals, Vice Principals, and Social Workers on Learning at Home

\begin{tabular}{llll}
\hline Item & Principals & $\begin{array}{l}\text { V. } \\
\text { Principals }\end{array}$ & $\begin{array}{l}\text { Social } \\
\text { Workers }\end{array}$ \\
\hline $\begin{array}{l}\text { 1. I provide parents with information that help them to } \\
\text { teach their children at home. }\end{array}$ & 3.95 & 3.58 & 4.05 \\
$\begin{array}{l}\text { 2. I encourage parents to borrow educational activities to } \\
\text { help their children learn. }\end{array}$ & 3.25 & 3.15 & 3.13 \\
3. I direct parents to learning resources in the community. & 3.66 & 3.51 & 3.90 \\
\hline
\end{tabular}

Fourth: Volunteering, most of the activities mentioned in Table 6 are used sometimes by school leaders to encourage volunteer activities by students and their parents. Asking parents to attend school activities, encouraging students to volunteer outside and inside school, and giving prizes and certificates to parents who voluntarily participate in school activities are the most often-seen practices in schools, while asking parents to join school teachers for field trips was the least practiced activity. Asking parents to volunteer is most commonly a task undertaken by social workers $(\mathrm{M}=4.09)$. Asking parents to participate in art displays and workshops for students are often activities that are done by school principals $(\mathrm{M}=4.17)$ and social workers $(\mathrm{M}=4.14)$.

Table 6. Responses of Principals, Vice Principals, and Social Workers on Volunteering

\begin{tabular}{|c|c|c|c|}
\hline Item & Principals & $\begin{array}{l}\text { V. } \\
\text { Principals }\end{array}$ & $\begin{array}{l}\text { Social } \\
\text { Workers }\end{array}$ \\
\hline 1. I ask parents to attend different school activities & 4.56 & 4.17 & 4.52 \\
\hline 2. I encourage students to volunteer outside and inside school. & 4.44 & 4.23 & 4.60 \\
\hline $\begin{array}{l}\text { 3. I conduct workshops for teachers to activate the communication } \\
\text { between teachers and volunteered parents. }\end{array}$ & 3.96 & 3.47 & 3.78 \\
\hline 4. I ask parents about the activities that they can do voluntarily. & 3.89 & 3.56 & 4.09 \\
\hline $\begin{array}{l}\text { 5. I ask parents to participate in art displays and different } \\
\text { workshops for students. }\end{array}$ & 4.17 & 3.79 & 4.14 \\
\hline 6. I encourage parents to present extra lessons. & 3.40 & 3.20 & 3.54 \\
\hline 7. I ask parents to join students in their field trips. & 3.35 & 3.20 & 3.60 \\
\hline 8. I ask parents to help teachers in the classrooms and labs. & 3.36 & 3.19 & 3.44 \\
\hline $\begin{array}{l}\text { 9. I encourage parents to provide school with educational } \\
\text { resources, art works and printed work. }\end{array}$ & 3.65 & 3.42 & 3.85 \\
\hline $\begin{array}{l}\text { 10. I give prizes and certificates to volunteered parents who } \\
\text { participate in the school activities. }\end{array}$ & 4.46 & 4.14 & 4.45 \\
\hline $\begin{array}{l}\text { 11. I gather information about parents who are willing to } \\
\text { participate in school's activities and their time availability }\end{array}$ & 3.69 & 3.50 & 3.90 \\
\hline $\begin{array}{l}\text { 12. I communicate with parents regarding providing public } \\
\text { libraries with copies of school books. }\end{array}$ & 3.72 & 3.18 & 2.98 \\
\hline
\end{tabular}

Fifth: Involving parents in making decisions, it is clear from the results in Table 7 that encouraging parents to attend the parents' councils meetings is the most common activity in school that is encouraged by principals $(M=4.86)$, vice principals $(M=4.61)$, and social workers as well $(M=4.83)$. 
Encouraging parents to participate in school management activities is often done by social workers $(\mathrm{M}=4.14)$. Asking parents to be involved in solving problems that are encountered in school is often a practice undertaken by school principals and social workers $(\mathrm{M}=4.05, \mathrm{M}=4.22)$. For social workers however, participating in school management and involving parents in solving school problems are the most common practices.

Table 7. Responses of Principals, Vice Principals, and Social Workers on Involving Parents in Making Decisions

\begin{tabular}{llll}
\hline Item & Principals & $\begin{array}{l}\text { V. } \\
\text { Principals }\end{array}$ & $\begin{array}{l}\text { Social } \\
\text { Workers }\end{array}$ \\
\hline $\begin{array}{l}\text { 1. I encourage parents to attend parents' councils } \\
\begin{array}{l}\text { 2. I encourage parents to participate in the school } \\
\text { management. }\end{array}\end{array}$ & 4.86 & 4.61 & 4.83 \\
$\begin{array}{l}\text { 3. I ask parents to be involved in solving problems that } \\
\text { encounter school. }\end{array}$ & 4.05 & 3.69 & 4.14 \\
$\begin{array}{l}\text { 4. I support parents being involved in reviewing school } \\
\text { curriculum. }\end{array}$ & 3.76 & 3.69 & 3.85 \\
5. I ask parents to suggest topics for workshops for parents. & 3.83 & 3.59 & 3.97 \\
\hline
\end{tabular}

Sixth: Communicating with the community, from the results in Table 8; one can conclude that the most common practice by school leaders in communicating with the community is to ask teachers and students to provide services to their communities (principals $M=4.45$, vice principals $M=4.20$, social workers $M=4.21$ ). Encouraging all community institutions to participate in school activities was the most often-practiced activity by school principals $(\mathrm{M}=4.33)$ and social workers $(\mathrm{M}=4.21)$. However, providing parents with information on available services in the community is most often done by social workers. Organizing programs for school in tandem with community institutions' support is the least common activity by school leaders, (school principals $\mathrm{M}=3.05$, vice principal $M=2.74$, and social workers $M=3.11$ ).

Table 8. Responses of Principals, Vice Principals, and Social Workers on Communicating with Community

\begin{tabular}{llll}
\hline Item & Principals & $\begin{array}{l}\text { V. } \\
\text { Principals }\end{array}$ & $\begin{array}{l}\text { Social } \\
\text { Workers }\end{array}$ \\
\hline $\begin{array}{l}\text { 1. I provide parents with information about available } \\
\text { services in their community. }\end{array}$ & 3.83 & 3.75 & 4.11 \\
$\begin{array}{l}\text { 2. I organize programs and activities for school with } \\
\text { community institutions support. }\end{array}$ & 3.05 & 2.74 & 3.11 \\
$\begin{array}{l}\text { 3. I encourage all community institutions to participate in } \\
\text { school activities. }\end{array}$ & 4.33 & 3.94 & 4.21 \\
$\begin{array}{l}\text { 4. I ask teachers and students to provide service to their } \\
\text { communities. }\end{array}$ & 4.45 & 4.20 & 4.21 \\
\hline
\end{tabular}

The second research question in this study was: "Is there a statistically significant difference in the way these practices of parental involvement by school leaders are carried out based on gender, school level, and job position?" To compare the way practices are carried out based on job position, the means of the responses of each of the six components were calculated for principals, vice principals, and social workers respectively, and summarized in the first three columns in Table 8. The last two columns contain the results of the Analysis of Variance (ANOVA) tests which were used to compare the three educators' groups.

As can be concluded from Table 9, the three groups of educators (principals, vice principals, and social workers) are significantly statistically different in their practices of encouraging parents to be engaged in their children's schooling in the areas of Parenting, Communication, Volunteering, and being Involved in Decision-Making, while differences in Learning at home and Communicating with Community were not found to be statistically significant. Further, based on overall means of the six types of involvement, it was seen that the vice school principal is less engaged in activities that encourage parents to be involved in their children's' education. 
Table 9. Means of Responses on Each Component by Job Position

\begin{tabular}{llllll}
\hline Component & Principals & Vice Principals & Social Workers & F Value & P Value \\
\hline Parenting & 3.63 & 3.27 & 3.83 & 18.53 & .00 \\
Communicating & 4.28 & 3.96 & 4.22 & 11.04 & .00 \\
Learning at home & 3.62 & 3.42 & 3.70 & 3.04 & .05 \\
Volunteering & 3.91 & 3.63 & 3.99 & 6.47 & .02 \\
Involving in Making Decisions & 4.09 & 3.86 & 4.21 & 7.20 & .00 \\
Communicating with Community & 3.93 & 3.65 & 3.92 & 4.49 & .01 \\
\hline
\end{tabular}

As for gender, responses on the six types of parental involvement were broken down by gender. The results for male and female leaders and the independent t-test values were calculated and summarized in Table 10. The results indicate that female leaders did more than their male conterparts to encourage parents to be engaged in schools. The independent t-test results indicated that there is a significant difference between males and females on three components: Parenting, Communicating, and Volunteering. The differences on the other three components were not statistically significant.

Table 10. Means of Responses on Each Component By Gender

\begin{tabular}{lllll}
\hline Component & Males & Females & T-Value & P value \\
\hline Parenting & 3.37 & 3.72 & -4.29 & .00 \\
Communicating & 4.04 & 4.22 & -3.14 & .00 \\
Learning at home & 3.49 & 3.64 & -1.54 & .12 \\
Volunteering & 3.49 & 4.06 & -6.71 & .00 \\
Involving in Making Decisions & 3.97 & 4.12 & -1.86 & .06 \\
Communicating with Community & 3.81 & 3.85 & -.45 & .65 \\
\hline
\end{tabular}

As for the school level, the participants represented three schooling levels in the UAE educational system: first segment, second segment, and secondary school level. The means of responses were calculated for each component at each school level, the results of which are presented in Table 10. To compare the results over the school levels, an ANOVA analysis was conducted, and the results were summarized in the last two columns in Table 11.

The differences among the three schooling levels were significant on the first four components: Parenting, Communicating, Learning at Home, and Volunteering. The differences in involving parents in Making Decisions and Communicating with Community were not statistically significant. Further, based on the overall means of the six types of parental involvement, school leaders in the first segment were seen to be more often engaged in activities to involve parents in their children's education.

Table 11. Means of Responses on Each Component by School Level

\begin{tabular}{llllll}
\hline Component & First Cycle & $\begin{array}{l}\text { Second } \\
\text { Cycle }\end{array}$ & $\begin{array}{l}\text { Secondary } \\
\text { School }\end{array}$ & F Value & P Value \\
\hline Parenting & 3.76 & 3.50 & 3.55 & 4.11 & .02 \\
Communicating & 4.31 & 4.05 & 4.16 & 6.81 & .00 \\
Learning at home & 3.82 & 3.49 & 3.46 & 5.55 & .00 \\
Volunteering & 4.17 & 3.69 & 3.77 & 12.02 & .00 \\
Involving in Making Decisions & 4.13 & 4.02 & 4.07 & .71 & .49 \\
Communicating with Community & 3.85 & 3.80 & 3.90 & .55 & .58 \\
\hline
\end{tabular}




\section{Discussion}

The purpose of this study was to explore the practices undertaken by school leaders (principals, vice principals and social workers) to engage parents in children's education, and to ascertain whether there is a statistically significant difference in the way these practices are carried out, based on gender, school level and job position. The results of the study showed that school leaders are active in communicating with parents and involving parents in making decisions about school.

It was seen also that school leaders use different communication methods for different issues, which is the common practice found to contribute to the positive attitudes of parents towards the school. On the other hand, school leaders rarely ask teachers to use the school phone to contact parents, even if parents prefer informal contact with the teachers, as Hornby (2011) and Cattermole and Robinson (1985) affirmed.

It was also seen that distributing a survey to know and understand students' weakness and strengths is not a common practice. However, it is a practice that needs to be considered in order to build an accurate student record. It is noteworthy that social workers often communicate with parents regarding student development or problems.

Based on the survey results, in general, it is seen that school leaders often involve parents in making decisions for schools. However, it is worth noting that parental involvement in schools is defined differently in the UAE than it is in the western world. In western literature, parental involvement in schools means that parents are involved in making decisions on school activities, and also support activities through the Parent-Teacher Association (PTA). The Parents-Teachers Associations (PTA) in UAE schools however, are more advisory in nature, and pertain more to student activities and behavior (Al-Taneiji, 2001 \& Al Sumaiti, 2012).

This means that involving parents in reviewing the school curriculum is less practiced in the UAE than elsewhere, due to the centralization of the education system. School principals and vice principals do sometimes encourage parents to participate in school management, which involves parents giving suggestions and advice on how to handle some of the problems faced in the school. Also, school leaders sometimes ask parents to suggest topics for workshops. School leaders often ask parents to attend the parents' council meetings, which is a requirement of the Ministry of Education.

School leaders need to focus on activities that inform parents about their children's growth in each stage because there is a positive relationship between parenting practices and style and students achievement. These activities might include workshops and providing parents with books, tapes and flyers (Areepattamannil, 2010).

School leaders must also encourage more learning-at-home activities by parents. While private tutoring is a common practice among UAE families, school leaders need to focus on this type of parental involvement because helping children at home has positive effects on their achievement (Harris and Goodall, 2008), specifically in certain subjects such as reading (Sukhram \& Hsu, 2012) and mathematics (Sheldon \& Epstein 2005).

It was also seen that school leaders do not often practice activities that encourage parents to volunteer in schools, except asking them to volunteer in school activities, and giving them certificates and prizes for volunteering. It is obvious that the social workers are more often the ones who ask parents to participate in school activities, displays and workshops for students because social workers are tasked mainly with student welfare and their social activities.

Finally, it is seen that school leaders do practice some activities in order to encourage parents to communicate with the community, for the sake of students and the school. An explanation for this behavior by school leaders could be that most of them communicate directly with the school community without encouraging parents to do so. The exception to this is when a parent actually represents one of the community institutions, thereby making the process of communication much easier.

The results of this study show that the ways school leaders involve parents in their children's education do differ according to gender, school level and job position. Female school leaders were found to be more proactive in involving parents. This could be explained by saying that female school principals usually exhibit feminist leadership, which has been described as "creating an empowering and caring school climate" (Strachen, 1999, p. 321), which motivates them to practice more activities that involve parents in school, for the sake of the students.

Schools leaders also have different job descriptions, which could explain the differences in the way they approach parental involvement. School principals and social workers are seen to be more active in parent involvement activities than vice principals, whose work primarily consists of what is delegated to him/her by the school principal, and which differs from school to school. 
Further, based on the overall means obtained in the six types of parental involvement, it was found that the first segment (elementary schools) leaders are more often engaged in activities that involve parents in their children's education. This could be because parents tend to engage more at this stage of their children's lives (Spera, 2005). Another explanation is that school leaders recognize the importance of involving parents in this level, so they offer more activities that support this involvement.

\section{Conclusion and Recommendations}

School leaders in UAE schools communicate often with parents and also engage them in school decisions. They also practice some activities regarding the following types of parental involvement: parenting, learning at home, volunteering and involving the community. The findings from this study indicate that school leaders in the UAE need to use different types of involvement strategies to involve parents in their children's education, and thereby strengthen the relationship between schools and parents.

This study has practical implications for educational leaders who are concerned about parental involvement. School leaders need to be nurtured and supported if they are to develop different practices that encourage more parental involvement, and thereby enhance the performance of students and teachers. Based on the study results and the literature review, having productive relationship between schools and parents' needs:

- Involving parents in a wider range of activities that help children succeed, particularly those that support learning at home and enhance the ability of parents to assist children with their education.

- Training school leaders in different strategies on how to involve parents more effectively.

- Supported policies and regulations in relation to working with parents, and parents need to know what type and level of involvement is expected from them.

- Involving parents in the education of children at all levels (elementary to secondary) is a crucial factor in student achievement, as recent studies have demonstrated. School leaders therefore need to carefully select parent involvement activities that strategically target parents of children in specific year levels, e.g. age-appropriate and relevant parent involvement activities would be offered for those with children in higher grades.

In addition to this, a qualitative study, exploring which specific activities could be used by principals to more fully engage parents in the life of the school, and especially, the education of their own children, would also be most useful.

\section{Acknowledgments}

The author would like to express her sincere appreciation to the Research Affairs at United Arab Emirates University for providing financial support under a contract no. 02-02-11-2011.

\section{References}

Al Sumaiti, R. (2012). Parental involvement in the education of their children in Dubai. Policy Brief, 30. Dubai School of Government.

Al-Taneijij, S. (2001). The relationship between successful schools and parental involvement in the United Arab Emirates. (Unpublished Doctoral Dissertation). University of Colorado at Denver, USA.

Areepattamannil, S. (2010). Parenting practices, parenting style, and children's school achievement. Psychological Studies, 55(4), 285-289. http://dx.doi.org/10.1007/s12646-010-0043-0

Badri, A. (1998). School Social Work and School Effectiveness in the Gulf States. School Psychology International, 19, 121-134. http://dx.doi.org/10.1177/0143034398192002

Bæck, U. (2010a). 'We are the professionals': a study of teachers' views on parental involvement in school. British Journal of Sociology of Education, 31(3), 323-335. http://dx.doi.org/10.1080/01425691003700565

Bæck, U. (2010b). Parental involvement practices in formalized home-school cooperation. Scandinavian Journal of Educational Research, 54(6), 549-563. http://dx.doi.org/ 10.1080/00313831.2010.522845

Bailey, L., Silvern, S., Brabham, E., \& Ross, M. (2004). The effects of interactive reading homework and parent involvement on children's inference responses. Early Childhood Education Journal, 32(3), 173-178. http://dx.doi.org/10.1023/B:ECEJ.0000048969.91442.36

Barnyak, N., \& McNelly, T. (2009). An Urban School District's Parent Involvement: A Study of Teachers' and Administrators' Beliefs and Practices. The School Community Journal, 19(1), 33-58. 
Barton, P. E., \& Coley, R. J. (2007). The family: America's smallest school. Princeton, NJ: Educational Testing Services.

Berger, E. H. (1991). Parents as partners in education. New York: Macmillan.

Boaduo, N. Adu-Pipim, Milondzo, K., \& Adjei, A. (2009). Parent-community involvement in school governance and its effects on teacher effectiveness and improvement of learner performance: A study of selected primary and secondary schools in Botswana. Educational Research and Review, 4(3), 096-105.

Bush T., \& Glover D (2002). School Leadership: Concepts and Evidence. Nottingham: National College for School Leadership.

Cattermole, J., \& Robinson, N. (1985). Effective Home/School Communication: From the parents' perspective. Phi Delta Kappan, 67(1), 48-50.

Chavkin, N., \& Williams, D. (1993). Minority parents and the elementary school: Attitudes and practices. In N. Chavkin (Ed.), Families and schools in a pluralistic society (pp. 73-83). Albany, NY: State University of New York Press.

Chen, W., \& Gregory, A. (2010). Parental involvement as a protective factor during the transition to high school. The Journal of Educational Research, 103, 53-62. http://dx.doi.org/10.1080/00220670903231250

Dixon, S. (2008). A study of parental involvement and school climate: Respective from the middle school. (Doctoral dissertation). Retrieved from http://repository.tamu.edu/bitstream/ handle/1969.1/ETD-TAMU-3070/DIXON-DISSERTATION.pdf?sequence=1

Epstein, J. (1995). School/family/community partnerships. Phi Delta Kappa, 76, 701-712.

Epstein, J. (2008). Improving Family and Community Involvement in Secondary Schools. Retrieved from http://olms.cte.jhu.edu/olms/data/resource/3881/Improving\%20Family\%20and\%20Community\%20Involve ment.pdf

Fan, X.T., \& Chen, M. (2001). Parental involvement and students' academic achievement: A meta-analysis. Educational Psychology Review, 13, 1-22.

Feuerstein, A. (2000). School characteristics and parent involvement: Influences on participation in children's schools. The Journal of Educational Research, 94(1), 29-40. http://dx.doi.org/ $10.1080 / 00220670009598740$

Fishel, M., \& Ramirez, L. (2005). Evidence-based parent involvement interventions with school-aged children. School Psychology Quarterly, 20, 371-402. http://dx.doi.org/ 10.1521/scpq.2005.20.4.371

Gay, L., Mills, G., \& Airasian, P. (2009). Educational Research: Competencies for Analysis and Application (9th. ed.). Upper Saddle River, NJ: Prentice Hall.

Gonzalez-DeHass, A. R., \& Willems, P. (2003). Examining the underutilization of parent involvement in the schools. School Community Journal, 13(1), 85-99.

Gordon, M., \& Louis, K. (2009). Linking parent and community involvement with student achievement: Comparing principal and teacher perceptions of stakeholder influence. American Journal of Education, 116(1), 1-31. http://dx.doi.org/ 10.1086/605098

Haastrup, I., \& Arogundade, B. (2009). Parents' involvement in school administration as a correlate of effectiveness of secondary schools in Nigeria. Journal of Education Administration and Policy Studies, 1(3), 41-046.

Harris, A., \& Goodall, J. (2008). Do parents know they matter? Engaging all parents in learning. Educational Research, 50(3), 277-289. http://dx.doi.org/10.1080/00131880802309424

Henderson, A. T., \& Mapp, K. L. (2002). A new wave of evidence: The impact on school, family, and community connections on student achievement. Southwest Educational Development Laboratory: Austin, TX.

Hill, N., \& Tyson, D. (2009). Parental Involvement in Middle School: A Meta-Analytic Assessment of the Strategies That Promote Achievement. Developmental Psychology, 45(3), 740-763. http://dx.doi.org/10.1037/a0015362

Hornby, G. (2011). Parental Involvement in Childhood Education: Building Effective School-Family Partnerships. Springer. New York. 
Huntsinger, C., \& Jose, P. (2008). Parental involvement in children's schooling: Different meanings in different cultures. Early Childhood Research Quarterly, 24, 398-410. http://dx.doi.org/10.1016/j.ecresq.2009.07.006

International Bureau of Education. (2011). World Data in Education. Retrieved from http://www.ibe.unesco.org/ fileadmin/user_upload/Publications/WDE/2010/pdf-versions/United_Arab_Emirates.pdf

Jacobs, B. (2008). Perspectives on parent involvement: How elementary teachers use relationships with parents to improve their practice. Dissertation submitted to the Faculty of the Graduate School of the University of Maryland, College Park in partial fulfillment of the requirements for the degree of Doctor of Philosophy

Lloyd-Smith, L., \& Baron, M. (2010). Beyond conferences: Attitudes of high school administrators toward parental involvement in one small Midwestern state. The School Community Journal, 20(2), 23-44.

Lunenburg, F., \& Irby, B. (2002). Parent involvement: A key to student achievement. ERIC Document No. ED468558.

Mapp, K. (2003). Having their say: Parents describe why and how they are engaged in their children's learning. School Community Journal, 13(1), 35-64.

Mitchell, C. (2008). Parent Involvement in Public Education: A Literature Review. Philadelphia: Research for Action.

Public Education Network. (2008). NCLB Glossary. Retrieved from http://www. publiceducation.org/ nclb_main/ Glossary.asp

Salinas, K. C., Epstein, J. L., Sanders, M. G., Davis, D., \& Douglas, I. (1999). Measure of school, family, and community partnerships [Teacher survey]. Baltimore, MD: Johns Hopkins University, \& Portland, OR: Northwest Regional Educational Laboratory.

Sanders, M. G., \& Epstein, J. L. (2000). Building school-family-community partnerships in middle and high school. In M.G. Sanders (Ed.), School students placed at risk: research, policy, and practice in the education of poor and minority adolescents (pp. 339-61). Mahwah, NJ: Lawrence Erlbaum Associates.

Sheldon, S., \& Epstein, J. (2005). Involvement counts: Family and community partnerships and math achievement. Journal of Educational Research, 98, 196-206. http://dx.doi.org/10.3200/JOER.98.4.196-207

Sills-Briegel, T., Bryant, S., \& Al Hashimi, W. (2009). The United Arab Emirates: Educating young Adolescents. In Mertens, S., Anfara, V., Roney, K. (Eds.), An international look at educating young adolescents. The handbook of research in middle level education. (pp. 47-72). United States: Information Age Publishing.

Simon, B. (2001). Family involvement in high school: Predictors and effects. NASSP Bulletin, 85(627), 8-19.

Simon, B. (2004). High school outreach and family involvement. Social Psychology of Education, 7(2), 185-209. http://dx.doi.org/10.1023/B:SPOE.0000018559.47658.67

Spera, C. (2005). A review of the relationship among parenting practices, parenting styles, and adolescent school achievement. Educational Psychology Review, 17, 125-146. http://dx.doi.org/10.1007/s10648-005-3950-1

Strachan, J. (1999). Feminist Educational Leadership: locating the concepts in practice [1]. Gender and Education, 11(3), 309-322.

Sukhram, D., \& Hsu, A. (2012). Developing Reading Partnerships Between Parents and Children: A Reflection on the Reading Together Program. Early Childhood Education Journal, 40(2), 115-121. http://dx.doi.org/10.1007/s10643-011-0500-y

Van Voorhis, F. L. (2001). Interactive science homework: An experiment in home and school connections. NASSP Bulletin, 85(627), 20-32. http://dx.doi.org/10.1177/019263650108562703 